\title{
AGAMA YAHUDI SEBAGAI FAKTA SEJARAH DAN SOSIAL KEAGAMAAN
}

\author{
Ilim Abdul Halim \\ Jurusan Perbandingan Agama Fakultas Ushuluddin UIN Sunan Gunung Djati Bandung \\ Jl. A.H. Nasution 105 Cibiru, Bandung 40614, Indonesia. \\ E-mail: ilimhalim@uinsgd.ac.id
}

\begin{abstract}
Some the term in literature english used to mention jews were; hebrew / hebron ( hebrew ), israelites ( orang-orang israel ), children of is mael ( anak-anak is mael), judeans ( orang-orang judah ) and jews ( orang-orang jewish). Jews can in terms of two sides : ethnic and religion. On one side were as an ethnic has played a variety of historical circumstances important in the dynamics of his life to be a record world history. A jewish religious sociological including having religious unsur-unsur the religious beliefs, religious experience, religious rituals and religious communities.
\end{abstract}

Keywor ds:

jews, history and religion.

\begin{abstract}
Abstrak
Beberapa istilah dalam literatur Inggris digunakan untuk menyebut Yahudi diantaranya; Hebrew/hebron (Ibrani), Israelites (orang-orang Israel), Children of Ismael (anak-anak Ismael), Judeans (orang-orang Judah) dan Jews (orang-orang Yahudi).Yahudi dapat ditinjau dari dua sisi yaitu etnis dan agama. Di satu sisi Yahudi sebagai etnis telah memerankan berbagai peristiwa sejarah penting dalam dinamika kehidupannya sehingga menjadi catatan sejarah dunia. Di sisi lain Yahudi sebagai agama memiliki corak keberagamaan tertentu yang berbeda dengan agama-agama lainnya dalam kehidupan. Secara sosiologis Yahudi termasuk agama karena memiliki unsur-unsur agama yaitu kepercayaan keagamaan, pengalaman keagamaan, ritual keagamaan dan komunitas keagamaan.
\end{abstract}

Kata Kunci:

Yahudi, sejarah dan agama.

\section{A. PENDAHULUAN}

Ada hal yang menarik dalam membahas keberadaan Yahudi dalam kehidupan dunia. Di satu sisi Yahudi sebagai etnis telah memerankan berbagai peristiwa sejarah penting dalam dinamika kehidupannya sehingga menjadi catatan sejarah dunia. Catatan sejarah menunjukkan bahwa bangsa Yahudi hidup selama 4000 tahun. Beberapa bangsa yang sejaman dengan bangsa Yahudi telah musnah, seperti Bangsa Babilonia, Persia, Phonenica, Hittite, dan Philistine. ${ }^{1}$ Selama 3000 tahun bangsa Yahudi tidak memiliki Negara sendiri, tetapi mempu bertahan hidup dan memelihara identitas etnik mereka di tengah kebudayaankebudayaan asing. Secara statistik mereka

\footnotetext{
${ }^{1}$ Max I. Dimont, Jews, God and History. Terjemahan Al Toro. Cet. Ke-1 (Bandung: Eraseni Media, 1993), II
}

termasuk kecil karena kurang dari setengah persen dari penduduk dunia yang dapat diklasifikasikan sebagai bangsa Yahudi, tetapi sepertiga dari kebudayaan Barat mempunyai ciri-ciri yang bersifat Yahudi $^{2}$, dan tidak kurang dari 12 persen dari semua peraih hadiah Nobel adalah orang-orang Yahudi. ${ }^{3}$ Tokoh-tokoh dunia dari etnis Yahudi pun muncul dalam catatan sejarah, diantaranya Yesus Kristus yang diklaim sebagai Putra Tuhan oleh umat Kristen; Karl Marx yang dianggap sebagai "Nabi"-nya aliran pemikiran Materialisme dan Komunisme; Sigmund Freud yang dianggap sebagai penemu psikoanalisa dalam psikologi; Baruch Spinoza yang disebut sebagai pembebas filsafat dari mistisisme dan mengarahkan pemikiran manusia

\footnotetext{
${ }^{2}$ Huston Smith, The Religions of Man. Terjemahan Saafroedin Bahar. Edisi Kedua (Jakarta: Yayasan Obor Indonesia, 1991), 298.

${ }^{3}$ Max I. Dimont, Jews, God and History, II.
} 
menuju rasionalisme dan sains modern. Tidak lupa pula Alabert Einstein dikenal sebagai penemu teori relativitas yang mengakibatkan penemuan senjata Bom pada abad modern ini. Tentu masih banyak lagi tokoh-tokoh dunia keturunan yahudi lainnya tercatat dalam catatan sejarah.

Di sisi lain Yahudi dalam kehidupan masyarakat internasional memiliki peran sebagai Agama yang memiliki corak keberagamaan tertentu yang berbeda dengan agamaagama lainnya. Selama 3000 tahun kekuatan spiritual juga intelektual, yang kini disebut agama telah dimiliki oleh Bangsa Yahudi. Keberadaan Agama Yahudi termasuk Agama Besar Dunia yang diklasifikasi dalam Agama Ibrahim (Abrahamic Religion) bersama dengan Kristen dan Islam. Keberadaan Agama Yahudi ini mengawali munculnya Agamaagama Besar lainnya seperti Kristen dan Islam. Menurut sebagian sejarawan ${ }^{4}$ bahwa Agama bangsa Yahudi telah mempengaruhi iman (faith) Agama Islam dengan konsep monoteisme yang bersumber dari ajaran Abraham (Ibrahim).

Dengan demikian peran Yahudi dalam sejarah kehidupan dunia tidak hanya sebagai etnis tetapi juga sebagai agama atau kekuatan spiritual. Hal ini menjadi penting untuk dikaji oleh warga dunia termasuk Akademisi Studi Agama- Agama dan Ummat Islam untuk mengenal dan mengerti bahwa Agama Yahudi sebagai fakta sejarah dan fakta sosial keagaman. Dengan kedua fakta itu dapat diketahui karakter dan interaksi Yahudi dalam dinamika kehidupannya. Oleh karena itu dalam tulisan ini penulis akan memaparkan beberapa hal penting, diantaranya; istilah-istilah yang berkaitan dengan Yahudi, sejarah singkat Yahudi, doktrin Agama Yahudi, ritual Agama Yahudi, pengalaman keagamaan Yahudi dan intitusi Agama Yahudi.

\section{B. HASIL DAN PEMBAHASAN \\ 1. Is tilah-istilah}

Terdapat beberapa istilah yang berkaitan dengan istilah Yahudi, baik dalam literatur

\footnotetext{
${ }^{4}$ Max I. Dimont, Jews, God and History, II.
}

bahasa Inggris maupun Arab. Dalam literatur Inggris diantaranya; Hebrew/hebron (Ibrani), Israelites (orang-orang Israel), Children of Ismael (anak-anak Ismael), Judeans (orangorang Judah) dan Jews (orang-orang Yahudi). Istilah Hebrew (Ibrani) berkaitan dengan masa Bapak-Bapak terdahulu, seperti Ibrahim, Ishak dan Yakub, dan Ibu-Ibu terdahulu; Sarah, Rebeca, Rachel, Leah dan anak-anak mereka. Istilah 'Israel" (Ibrani; yisrael) bisa bermakna seseorang yang berjuang dengan Tuhan. Duabelas anak Yakub mewakili dua belas suku Israel, dan anggota suku itu dikaitkan dalam Bibel sebagai anak-anak Israel (Ibrani; bani yisra'el) atau secara singkat Israel. Istilah Israel duga dipakai untuk menyebut bangsa Yahudi setelah keluar dari Mesir. Istilah Judeans (Hebrew; Yahudim) berkaitan dengan salah satu suku yang timbul akibat dari pembagian wilayah Israel setelah Sulaiman meninggal. Karena variasi bahasa dalam Bahasa Inggris, istilah Judah menjadi Jews (orang-orang Yahudi) dalam bahasa Inggris. Jadi istilah Yahudi kemungkinan berasal dari bahasa Ibrani yaitu Yahudim.Dalam bahasa Arab terutama dalam Al-Qur'an terdapat dua istilah yang berbeda. Kedua istilah itu adalah Bani Israel dan Yahud (alladhina hadu). Istilah Bani Israel berhubungan dengan orangorang Israel sebagaimana terdapat dalam Bibel, sedang istilah "Yahud" memberikan arti orang-orang Yahudi (Jews) yang sejaman dengan Muhammad. ${ }^{5}$

\section{Agama Yahudi sebagai Fakta Sejarah}

Sejarah Yahudi baik sebagai bangsa maupun agama bersumber dari fakta sejarah Kitab Suci yang bernama Bibel disertai dengan bukti sumber lain seperti artifak kuno, kronologi kerajaan atau arsip kerajaan tetangga, arsip buku lainnya dan arkeologi. Para sejarawan terkadang menganggap mitos terhadap fakta sejarah yang berupa kitab suci itu. Timbulnya sejarah yang diikuti dengan

\footnotetext{
5 Reuven Firestone, Children of Abraham- An Introduction to Judaism for Muslims (USA: The Harriet and Robert Heilbrunn Institute for International Interreligious Understanding of the American Jewish Committee, 2001), 2.
} 
mitos ini disebut sejarah suci (sacred history). sejarah dan mitos muncul dalam pembahasan sejarah agama Yahudi dan orang Yahudi dahulu sebagaimana munculnya dunia kuno. Begitu pula secara akademik sejarah Agama Yahudi bersumber dari Bibel Yahudi. Selain itu untuk memahami Yahudi sebagai agama dalam tulisan ini dapat direspon dengan kitab suci lainnya, termasuk Al-Qur'an sebagai pembanding.

Para ahli Ilmu Agama mengungkapkan bahwa kisah Agama Yahudi berawal dari peristiwa hijrah dan Perjanjian. Peristiwa hijrahnya Ibrahim dari kota Ur di Chaldea (Babylonia) ke daerah "Canaan" (kini Palestina) sekitar Tahun 2000 S.M ${ }^{6}$ merupakan awal sejarah Agama Yahudi. Pada saat itu kekaisaran Babilonia dipimpin oleh Hamurabi dan pada saat yang sama kekaisaran Mesir sedang memperluas daerah kekuasaannya. Dalam Bibel diceritakan bahwa Tuhan menjadikan Ibrahim seorang yang taat kepada Tuhan dan memanggil Ibrahim untuk meninggalkan tanah kelahirannya dan menjanjikan dia berkat yang besar. Sebagaimana dalam kejadian 12:1 bahwa :

Tuhan berkata kepada Ibrahim, "pergilah jauh dari kampung halamanmu dan dari rumah bapakmu menuju tanah yang aku akan tunjukan kepadamu. Aku akan membuat kamu bangsa besar, Aku akan memberkatimu, Aku akan membuat namamu besar. Kamu seharusnya menjadi berkat, Aku akan memberkati siapa saja yang memberkatimu, dan akan mengutuk siapa saja yang mengutuk kamu, dan semua keluarga di bumi akan diberkati oleh kamu.

Perintah ini dikarenakan peringatan ajaran ketuhanan yang monoteis dan pengaruh buruk yang akan ditimbulkan dari Raja Namrud kepada Ibrahim. Ibrahim pergi dari daerahnya

\footnotetext{
${ }^{6}$ S.M adalah singkatan dari sebelum masehi, dalam bahasa Inggris biasanya digunakan $\mathrm{BCE}$ (Before the common Era) adalah bersifat universal -berlawanan dengan Kristen cara menyebutkan tanggal pada kalender Barat. BCE lebih baik daripada B.c (Before Christ) dan C.E (Common Era) daripada A.D (Anna Domini)Tahun Tuhan Kita. Moojan Momen, The Phenomenon of Religion- A Thematic Approach (Washington: Oneworld. 1999), 455.
}

di sebelah Timur sungat Eufrat (Irak) ke daerah Canaan (Palestina) bersama isterinya Sarah, kemenakannya lot bin haran dan beberapa keluarga lainnya. Namun ketika terjadi kelaparan di Canaan, Ibrahim bersama keluarganya pindah lagi ke Mesir "bekerja sama" kepada Raja Firaun dan menyerahkan Sarah yang dikatakannya sebagai adiknya. Akibat balas jasa itu Ibrahim mendapat hadiah ternak dan beberapa budak, diantaranya bernama Hajar. Akibat Raja Firaun memperisteri Sarah keadaan menjadi kacau, maka Sarah dikembalikan lagi kepada Ibrahim dan mereka diusir dari Mesir. Ibrahim dan keluarganya pergi ke daerah Negeb dekat Betel (kejadian: 13).

Dalam peristiwa perjanjian disebutkan bahwa Tuhan telah menetapkan perjanjian dangan Ibrahim suatu perjanjian abadi atau kontrak Tuhan dengan Ibrahim dan keturunannya bagi Agama Yahudi sebagaimana disebutkan dalam kejadian 17 bahwa;

Ketika Ibrahim berusia sembilan puluh sembilan Tahun Tuhan mengangkat Ibrahim dan berkata kepadanya, "Aku Tuhan yang Maha Kuasa, kamu akan benar jika kamu berjalan di jalan Ku. Aku akan menetapkan perjanjian- $\mathrm{Ku}$ antara Aku dan Kamu, Aku akan membuatmu keturunan yang banyak..... Kamu seharusnya akan menjadi Bapak dari berbagai bangsa.... Aku akan menjaga perjanjian-Ku antara Aku dan Kamu juga keturunanmu yang akan datang sebagai perjanjian abadi.....Aku menetapkan tanah tempat tinggal bagi kamu dan keturunanmu yang datang, yaitu tanah "Canaan" sebagai tempat abadi selama Aku adalah Tuhan mereka.

Bagi orang Yahudi, Ibrahim adalah Bapak mereka dan perjanjian ini dipahami tidak hanya persoalan teologi, tetapi juga berlanjut kepada persoalan sosial politik. Dengan pemahaman ini, sebagian orang Yahudi memahami bahwa Agama dan etinis menyatu. Begitu pula antara teologi dan sosial politik tidak bisa dipisahkan. Perjanjian ini kelak menjadikan agama Yahudi sebagai agama bangsa. 
Tokoh Ibrahim bagi tradisi Yahudi memberi suatu paradigma sifat-sifat manusia yang bernilai. Dia sabar dalam penderitaan, pecinta perdamaian (Kitab Kejadian 13:8-9), ramah terhadap orang tak dikenal (18:1), memperhatikan keselamatan orang lain (18:23-33), menjalankan penyebaran hal-hal yang bersifat ideal semacam keadilan dan kebenaran kepada keturunannya (18:19), dan selalu taat kepada Tuhan dan perintah-Nya.

Dalam Bibel disebutkan Ibrahim memiliki keturunan anak Ismael dan Ishak dari ibu yang berbeda. Ismael dari Hajar dan Ishak dari Sarah. Keturunan tersebut sangat diharapkan terutama menjelang kelahiran anak pertamanya yang membutuhkan waktu yang cukup lama.

Dalam tradisi Yahudi dari keturunan Ibrahim yang meneruskan perjanjian itu adalah Ishak. Sebagaimana disebutkan Tuhan memberkati Ismail, tetapi menjanjikan Ibrahim dan Sarah yang kelak anaknya bernama Ishak akan menjadi anak Ibrahim yang tetap berhubungan dalam perjanjian dengan Tuhan (Kejadian 17:20).

Bagi Ismael, Aku telah memperhatikan kamu dan dengan ini Aku memberkatinya. Aku akan membuatnya subur dan tak terkira banyaknya. Dia akan menjadi seorang Bapak dari duabelas suku, dan Aku akan membuatnya bangsa besar. Namun mengenai perjanjian- $\mathrm{Ku}$, Aku akan memelihara Ishak yang dengan Sarah akan melahirkan kamu pada tahun berikutnya.

Alasan Ismael tidak diikutsertakan dalam perjanjian itu tidak pernah dijelaskan dalam Bibel. Para ahli cenderung percaya bahwa tujuan cerita ini, seperti banyak cerita lainnya dalam kitab kejadian, adalah untuk menjelaskan hubungan etnik dan bahasa yang erat antara orang Israel dan orang-orang diantara mereka yang hidup. Dalam Kitab Kejadian 21, Hajar dan Ismael dikirim jauh dari suku Ibrahim, sedikit sekali terdengar soal Ismael dan keturunannya dalam Bibel. Menurut tradisi Yahudi, Ibrahim memelihara hubungan dengan anaknya Ismael namun Agama Yahudi tidak mengetahui sesuatu pun soal Ibrahim dan Ismael membangun dan memurnikan Ka'bah, dan Ibrahim menetapkan Ismael dan keturunannya di sana. ${ }^{7}$

Sejarah Yahudi dilanjutkan dengan peristiwa Yakub dan keturunannya. Yakub ini adalah keturunan dari Ishak. Dalam tradisi Yahudi Yakub dikenal sebagai Bapak dari duabelas anak yang memiliki suku-suku Israel. Keturunan Yakub selanjutnya adalah Yusup (Yoseph). Cerita Yusup ini menarik bagi para penganut agama Yahudi dan Islam. Cerita Yusup dengan saudara-saudaranya terdapat dalam Bibel dan Al-Qur'an. Dalam sejarah Yahudi tercatat bahwa menjelang tahun 1600 S.M., Yoseph membawa bangsa Yahudi menuju Mesir. Sekitar tahun 1200 S.M., Firaun (Pharoh-pharoh) memperbudak mereka.

Ketika supremasi Mesir mengalami tantangan, bahkan terjadi revolusi internal dan perang sipil di Mesir sekitar tahun 1500-1250 S.M., Musa (Moses) yang keturunan Yusup memimpin bangsa Yahudi meninggalkan Mesir. Peristiwa ini dalam tradisi Yahudi disebut exodus (keluaran) yang dijadikan nama salah satu Kitab dari Bibel. Dalam peristiwa ini Musa diyakini oleh penganut Yahudi mendapatkan ajaran berupa wahyu dari Tuhan di bukit Sinai. Kelak wahyu tersebut dijadikan Kitab Suci oleh penganut Yahudi. Selama empatpuluh tahun mengembara di gurun bangsa Yahudi mengalami berbagai pengalaman keagamaan. Bibel sering menggambarkan bangsa Israel tidak mampu untuk berbuat sesuai dengan perintah Tuhan. Di tengah gurun mereka menyembah Anak Lembu Emas (Kitab Keluaran 32) ${ }^{8}$ gagal meyakinkan Tuhan untuk masuk ke Negeri yang dijanjikan setelah mendengar laporan dari duabelas pengintai (Kitab Bilangan 1213), dan secara berulang-ulang mengadukan nasib mereka. ${ }^{9}$ Ritual keagamaan ini merupakan pengaruh dari kepercayaan bangsa Mesir, sebagaimana seorang penulis Kristen, Richard Rives dalam Buku Too Long in the

\footnotetext{
${ }^{7}$ Lihat Al-Qur'an 2:125-128,395-397, 14;37.

${ }^{8}$ Lihat Al-Qur'an 2:51-54, 92-93, 4:153, 7:152.

9 Lihat Kitab Keluaran 5:21, 14:11-12, 15:24, 16:28,17:2-7, Kitab Bilangan 11:4-6,14:1-4, 20:2-5, 21:4-5.
} 
Sun, menulis, " Hathor dan Aphis adalah dewa-dewa sapi betina dan jantan bangsa Mesir yang merupakan lambang dari penyembahan matahari. Penyembahan mereka hanyalah satu tahapan dalam sejarah pemujaan matahari oleh bangsa Mesir. Anak sapi emas di Gunung Sinai adalah bukti yang lebih dari cukup untuk mengetahui bahwa pesta yang dilakukan berhubungan dengan penyembahan matahari." 10

Menurut Firestone ${ }^{11}$ Bangsa Israel sepenuhnya adalah manusia, mereka secara moral lemah dan cenderung kalah terhadap godaan, mereka sering gagal melakukan sesuatu yang baik. Di sinilah gunanya sejarah Bibel baik berupa syair nasional, maupun kisah moral. Bahkan dengan hukum Tuhan, Israel selalu tidak bisa berbuat sesuai dengan persyaratan ketuhanan. Kegagalan manusia merupakan bagian dari kehidupan, namun dalam setiap peristiwa gagal, ada juga cahaya harapan, karena Tuhan memberi maaf dan karena orang berbudi mempertunjukan sikap kepahlawanan dan perilaku moral, sebenarnya Israel bertahan dan masuk ke Tanah yang dijanjikan walaupun sebagai orang yang berkekurangan. Menjelang tahun 1100 S.M., bangsa Yahudi menaklukkan suku Bangsa Canaan di Palestina.

Selama di Canaan bangsa Yahudi dipimpin oleh kepala suku yang disebut Hakim. Kemudian pemerintahannya berkembang menjadi kerajaan. Raja pertama bangsa Yahudi adalah Saul. Tercatat pula dalam sejarah bahwa Raja Daud dan Sulaeman (Solomon) pernah memimpin bangsa Yahudi. Diantara prestasi Daud adalah penetapan Yerusalem sebagai kota kerajaan sekitar tahun 1000 S.M. Sebelum penangkapan Daud dari kota itu dari Jebusit. Kota itu salah satu dari beberapa bagian negeri yang tidak di bawah pengawasan seseorang atau yang lainnya dari duabelas suku. Yerusalem dikenal sebagai tempat suci bahkan sebelum Ibrahim karena memiliki suasana dan tempat sakral untuk menyembah

10 Richard Rives, Too Long in The Sun (Partakers Pub, 1996), 130-131

11 Reuven Firestone, Children of Abraham- An Introduction to Judaism for Muslims, 19.
Tuhan yang dikenal sebagai El Elyon, "Tuhan Yang Mahatinggi" (Kitab Kejadian 14:1720). ${ }^{12}$ Kota itu merupakan kota sempurna bagi kerajaan Daud yang bersatu, karena kondisinya berada di luar wilayah suku sehingga secara politik netral, karena berada di tengah telah dikenal sebagai kota suci, dan tetap bertahan.

Raja Sulaeman membangun tempat Ibadah pertama bangsa Yahudi -kini tinggal puingpuingnya sebagai tembok ratapan. Sekitar tahun 900 S.M setelah Raja Sulaeman bangsa Yahudi terbagi dalam dua kerajaan. Sebelah utara, terdiri dari sepuluh suku dan mengambil nama Israel. Kerajaan sebelah selatan didominasi oleh suku Judah (Ibrani; Yehudah) dan mengambil namanya Judah. Pada tahun 721 S.M., kerajaan Assiria menghancurkan kerajaan sebelah utara Israel dan rakyatnya yang tinggal hanya suku Judah yang berada di sebelah selatan dengan penduduknya disebut orang-orang Judah atau Judean (Ibrani: Yahudim). Sejak peristiwa itu orang-orang menyebut mereka dengan Judah atau Judean. Bangsa Israel ditangkap dan diceraiberaikan sehingga akhir dari kerajaan bangsa Yahudi.

Selanjutnya sejarah Dunia tahun 700 S.M., mencatat bahwa Kerajaan Assiria ditaklukkan oleh Babylonia yang bangkit kembali. Sekitar tahun 600 S.M., bangsa Yahudi dideportasi ke Babylonia. Di Babiloni bangsa Yahudi mengalami perbudakan kembali. Namun zaman berubah setelah kekuasaan dunia berlanjut kepada kerajaan Persia setelah menaklukkan Babilonia sekitar tahun 500 S.M., dan gelombang pertama bangsa Yahudi pulang dari Babylonia membangun kembali tempat Ibadah. Sekitar tahun 457 S.M, gelombang kedua bangsa Yahudi pulang dipimpin oleh Ezra. Ezra dikenal dalam sejarah dunia sebagai pemimpin pembaharuan (restorasi) Agama Yahudi, karena dia memperbaiki sistem agama dan sosial Yahudi. Sebagaimana dalam Bibel disebutkan bahwa Ezra mengatur kembali masyarakat, membaca keras seluruh Taurat secara umum dan meminta orang-orang

\footnotetext{
${ }^{12}$ Arthur Green, Jewish Spirituality - From The Bible Through The Middle Ages (New York: The Crossroad Publishing Company. 1996), 5.
} 
Judah kembali menyatukan diri untuk menghormati perintah-perintah tradisi dan ritual bangsa Yahudi (Nehemiah 9-10).

Terdapat akibat yang ditimbulkan kepemimpinan Ezra, pertama, mengubah Agama Yahudi dari Agama etnik lokal menjadi agama universal. Sebelum pembuangan, semua agama-agama manusia dilokalisasi (bersifat kedaerahan). Hal ini diduga bahwa jika seseorang pindah ke negeri lain, orang itu akan menyembah Tuhan baru. Konsep Tuhan universal hanya datang ketika orang-orang Judah yang terbuang mendesak untuk meneruskan menyembah Tuhan Israel mereka, walaupun di tanah asing di Babilonia. "Tuhan Israel" membuktikan kenyataan di Babilonia sebagaimana di Yerusalem, sehingga mempertunjukkan keesaan dan keuniversalan Tuhan yang Mahaesa. Kedua, pembuangan itu membuktikan orangorang Judean bahwa mereka bisa menyembah Tuhan, walaupun tanpa pengorbanan formal di tempat ibadah yang talah dihancurkan. Sebelum masa pembuangan Babilonia, penyembahan Tuhan dalam semua agama dilakukan melalui pengorbanan di tempat ibadah atau di tempat suci. Mungkin kali pertama pengorbanan formal lainnya melebihi daripada pengorbanan binatang yang nampaknya telah melahirkan kepentingan di Babilonia yang jauh dari tempat ibadah Yerusalem, mereka harus merencanakan makna lain dari menyembah Tuhan. Peristiwa ini berpengaruh pula dalam sistem ritual Synagog, Greja dan Mesjid. $^{13}$ Namun tempat ibadah kedua ini dihancurkan oleh orang-orang Romawi. Upaya perbaikan Agama Yahudi yang dilakukan Ezra ditemani oleh Nehemiah. Ezra dan Nehemiah berupaya menyusun kitab Taurat itu -yang kini dijadikan kitab yang bersifat ketuhanan, sehingga agama Yahudi berkarakter nasional relijius dan spiritual.

Selama masa kekuasaan Helenisme di bawah pimpinan bernama Antiochus IV, Judea menderita dari perang sipil yang hampir menghancurkan seluruh rakyat Yahudi. Kelompok konservatif dikenal sebagai Maccobees menang dengan mengajukan orang-orang

\footnotetext{
13 Reuven Firestone, Children of Abraham- An Introduction to Judaism for Muslims, 28.
}

Helenisme radikal pada tahun 168 sebelum masehi dan mengukir Negara Yahudi independen yang memelihara cara-cara lama. Kemenangan atas tradisi ini ditandai dengan perayaan Hanukkah yang mengingatkan pengabdian kembali di tempat ibadah Yerusalem, yang telah dirusak oleh orangorang Yunani dan sekutu Yahudi Helenatis secara radikal.

Ketika berhadapan dengan penganut Kristen, Kebanyakan orang-orang Yahudi menolak untuk menerima ke-Juru Selamat-an Yesus, karena menurut Agama Yahudi, Juru Selamat yang benar akan membawa keselamatan dengan segera, tidak memerlukan "kedatangan kedua". Karena para penganut Yesus mulai membutuhkan keyakinan bahwa Yesus juga diakui Anak Tuhan, Kristen bergerak melewati batas penerimaan keyakinan Yahudi. Agama Yahudi menganggap konsep Kristen Trinitas menjadi pelanggaran keesaan Tuhan. Penolakan absolute yang diberikan oleh Agama Yahudi terhadap keyakinan Kristen bahwa Yesus adalah Anak Tuhan,

Memasuki kekuasaan Romawi sejak abad pertama masehi, Romawi secara tegas menetapkan aturannya tentang Judea (Yahudi). Gubernur dan pejabat pengadilan Romawi menjadi lebih bersikap keras bahkan sampai tidak adil. Pada tahun 66 orang-orang Yahudi memberontak yang dipimpin oleh bangsa Zealot yang meyakini bahwa Tuhan akan membantu mereka dalam perangnya melawan kaum kafir Romawi dan membawa Hari Akhir yang diharapkan. Namun orang-orang Yahudi tidak semuanya satu pendapat terhadap pemberontakan itu. Sebagian besar meyakini bahwa hal itu bukanlah waktu yang tepat atau perang itu bukanlah cara yang tepat dalam mewujudkan penyelamatan. Bangsa Yahudi memberontak terhadap Romawi menyebabkan kekacauan besar di kerajaan Romawi dan pasukan dibawa dari berbagai belahan Eropa dan Timur Tengah untuk mengatasinya. Akhirnya Romawi berhasil mendapatkan pengawasan Yerusalem pada tahun $70 \mathrm{M}$, dan menghancurkan tempat ibadah yang sedang dibangun itu. Begitu pula ketika berhadapan dengan kelompok Muslim, mereka tidak mau 
mengakui menjadi Muslim karena sebagaimana tradisi yang terjadi pada saat itu bahwa Muhammad tidak sesuai dengan harapan khusus mereka tentang seorang yang dinantikan.

Selanjutnya bangsa Yahudi memasuki masa-masa lainnya diantaranya; masa eropa modern, masa semangat nasionalisme, pebentukan Zionisme, peristiwa Holocaust, pembentukan negara Israel, masa penyebaran ke berbagai wilayah dunia -termasuk Indonesia ${ }^{14}$,dan zaman post modern.

\section{Agama Yahudi sebagai Fakta Sosial Keagamaan}

Agama dalam konteks sosial dapat dilihat dari empat aspek yaitu kepercayaan keagamaan, pengalaman keagamaan, ritual keagamaan dan Komunitas keagamaan, ${ }^{15}$ walaupun terdapat beberapa dimensi lain yang diungkap ahli agama lainnya. ${ }^{16}$ Begitu juga dalam melihat Agama Yahudi dalam konteks social dapat ditinjau dari empat aspek tersebut.

Kepercayaan Keagamaan

Kepercayaan keagamaan (religious belief) berupa gagasan ide-ide atau pemikiran dan peraturan-peraturan yang berkaitan dengan Agama, atau berisi doktrin ajaran keberagamaan. Doktrin atau ajaran itu bersumber dari yang dianggap suci -sacred dan biasanya ditulis dalam bentuk Kitab Suci. Doktrin Keagamaan Yahudi menyangkut berbagai hal, diantaranya konsep Ketuhanan, Alam, Umat Pilihan, moral, asketis dan sebagainya.

Gagasan pemikiran ketuhanan Agama Yahudi adalah monoteisme, secara sederhana diartikan Tuhan yang Mahaesa. Istilah Tuhan

\footnotetext{
${ }^{14}$ Dipermulaan abad ke-20, sekelompok orang Yahudi memasuki Indonesia melalui Surabaya sebagai pedagang. Disana seorang lelaki bernama Abraham yang kelahiran Indonesia menikah dengan Leah seorang wanita Yahudi kelahiran Bombay. lihat Jessica Champagne dan Teuku Cut Mahmud Azis, Komunitas Yahudi Surabaya, dalam Jurnal Agama \& Sains, ReliefJournal of Religious Issues, Yogyakarta, Volume I, Nomor 1 Januari 2003, 77.

15 Meredith B. McGuire, Religion, The social Context (California: Wadsworth,Inc., 1981), 11.

16 Menurut Ninian Smart terdapat enam dimensi keagamaan. Capps, Walter H. Religious Studies The Making of a Discipline. (USA: Fortress Press., 1995), 307.
}

dalam Agama Yahudi dengan bahasa Ibrani adalah YHWH dibaca "Yahweh" diterjemahkan dalam bahasa Inggris dengan kata "Lord". Yahweh dikenal juga sebagai dalam bahasa Ibrani El, Elohim, (El) Shaddai, (El) Elyon dan Adonai. ${ }^{17}$ Diterjemahkan dalam bahasa Inggris dengan kata "God". ${ }^{18}$ Mungkin dalam Bahasa Arab istilah Yahweh disebut "Ya Hua" artinya "Dia". Yahweh disembah oleh semua penganut Agama Yahudi. Agama Yahudi melarang menerima berbagai Tuhan (Politeisme), menyembah Patung. Keesaan (monoteis) Tuhan diyakini penganut Yahudi cenderung sebagai yang Mahakuasa, pencipta dunia, pembuat hukum alam dan pemberi aturannya. Tuhan melewati sifat dunia dan Tuhan itu abadi. Tuhan mendahului alam, semua yang lain pasti binasa, Tuhan akan hidup selamanya.

Penganut Agama Yahudi yakin bahwa alam semesta diciptakan Tuhan, dalam sejarahnya hanya bangsa Yahudi yang mengakui keesaan Tuhan sejati. Mereka percaya bahwa tak ada penduduk lain di bumi yang menyatakan kebenaran keesaan Tuhan dan tetap loyal kepada kebenaran itu. Sehingga mereka menganggap bahwa Bibel memerintahkan kepada hampir seluruh Israel secara ekslusif, karena tidak ada penduduk atau penganut lain yang bisa memahami dan meresponnya secara efektif.

Dengan pemahaman ini penganut Agama Yahudi dan penduduk Israel percaya bahwa Tuhan telah mengatur Israel menjadi "penduduk yang berharga" the Choosen peope milik Tuhan (am segullah). Mereka percaya bahwa Israel menjadi terpilih oleh Tuhan dengan adanya perjanjian antara Ibrahim dan keturunannya dengan Tuhan; dan diberinya Taurat (Ajaran) kepada Musa, sehingga penduduk Israel mesti menjadi "orang-orang pilihan" yang tetap loyal perintah Tuhan meskipun mereka menganggap banyak godaan yang dilambangkan dengan berbagai peradaban manusia di sekelilingnya.

\footnotetext{
17 Arthur Green, Jewish Spirituality - From The Bible Through The Middle Ages, 5.

18 Arthur Green, Jewish Spirituality - From The Bible Through The Middle Ages, 5.
} 
Para penganut Agama Yahudi yakin bahwa Tuhan sebagai pemberi Hukuman. Mereka percaya bahwa Tuhan telah memberi ajaran kepada penganut Agama Yahudi, berupa aturan-aturan perilaku spiritual, ritual, sosial, moral dan sebagainya. Penganut Yahudi percaya bahwa Tuhan akan menghukum manusia selama manusia memiliki banyak dosa, tetapi Tuhan adalah Maha Pengasih dan Pemaaf bagi manusia yang memiliki kelemahan. Pemahaman ini dapat disebut rasional, karena berkaitan dengan sebab akibat.

Berkaitan dengan ajaran moral Agama Yahudi sebagaimana tercantum secara eksplisit dalam Taurat sebanyak 613 perintah Tuhan terdiri dari 248 kewajiban pelaksanaan dan 365 perintah larangan. Secara singkat terangkum dalam sepuluh perintah Tuhan yaitu; 1). Akulah Yahweh Tuhanmu, 2) Jangan ada Tuhan lain padamu di hadapan-Ku, jangan membuat patung, 3) Jangan menyebut nama Tuhan dengan sembarangan, 4) Ingatlah kekudusan hari Sabbath, 5) Hormatilah ayahmu dan ibumu, 6) Jangan membunuh, 7) Jangan berzinah, 8) Jangan mencuri, 9) Jangan mengucapkan saksi dusta, 10) Jangan menginginkan rumah (harta, istri/suami, milik) sesamamu.

Doktrin Agama Yahudi mengajarkan pula tentang kehidupan setelah kematian seperti Kristen dan Islam. ${ }^{19}$ Sebagaimana tercatat dalam Talmud dan Midrash yang dikutif bahwa jiwa itu meninggalkan tubuh setelah meninggal, namun memelihara hubungan sementara dengannya selama setahun sampai tubuhnya membusuk sepenuhnya. Berbagai pendapat berbeda diantara para guru-guru Yahudi mengenai hal ini. Sebagian pendapat melihat bahwa jiwa-jiwa yang benar masuk surga selanjutnya, sedangkan jiwa yang bersalah menderita di Gehenna atau tidak mampu membebaskan dirinya dari tubuh yang membusuk sampai tahun itu berlalu. Sehingga dalam masa itu anggota keluarga yang masih hidup mendoakan orang yang telah meninggal itu (kaddish), karena perilaku anggota keluarga yang baik (anak sholeh) akan membantu jiwajiwa orang yang telah meninggal masuk surga.

19 Reuven Firestone, Children of Abraham- An Introduction to Judaism for Muslims, 221.
Setelah satu tahun di pasanglah batu nisan dan ucapan orang yang berduka berhenti kecuali pada peringatan kematian.

Kemudian doktrin kebangkitan Agama Yahudi mengajarkan bahwa kematian itu akan dihidupkan kembali demi pengadilan terakhir. Terdapat berbagai pendapat mengenai siapa saja yang akan dibangkitkan selama pengadilan itu. Sebagian pendapat menjelaskan bahwa hanya orang-orang Israel yang akan dibangkitkan dan diadili. Sebagian besar pendapat menjelaskan bahwa kebangkitan itu berlaku bagi semua manusia. Sebagaimana menurut Rabbi Joshua b. Hanoniah bahwa orang-orang non Yahudi mempunyai tempat di dunia yang akan datang. Kebangkitan itu bersatunya tubuh dan jiwa demi pengadilan terakhir, karena hal itu tidak mungkin diadili secara terpisah. ${ }^{20}$

Gagasan-gagasan keagamaan dalam Agama Yahudi termuat dalam beberapa jenis, terutama dalam teks kitab suci, walaupun terdapat pula dalam pemikiran filosof dan mistik kabalah. Kitab Suci itu merupakan teks-teks yang berisi gagasan ide dan peraturan yang berkaitan dengan Agama. Dalam Agama Yahudi terdapat teks-teks yang dijadikan pedoman beragama diantaranya; Tanakh, Talmud Midrash, Halakhah dan Aggadah. Tanakh dalam bahasa Inggris disebut Hebrew Bible (Bibel Yahudi). Tanakh ini merupakan akronim dari Torah (Taurat), Nevi'im (Para Nabi) dan Ketuvim (Tulisantulisan). Taurat sebagai diyakini penganut Yahudi sebagai ajaran yang diterima Musa langsung dari Tuhan/ Yahweh di Gunung Sinai. $^{21}$ Kitab ini berisi aturan ketuhanan menyangkut perilaku, cerita sejarah dunia, umat manusia dan asal usul orang Israel. Nevi'im berisi penjelasan perkembangan sejarah Israel dari penaklukan tanah Israel di bawah Josua sampai penaklukan tempat suci pertama. Ketuvim berisi kumpulan cerita dan syair tentang ajaran moral, etika social,

\footnotetext{
20 Reuven Firestone, Children of Abraham- An Introduction to Judaism for Muslims, 221.

${ }^{21}$ Reuven Firestone, Children of Abraham- $A n$ Introduction to Judaism for Muslims, 114.
} 
kedudukan manusia di bumi dan hal-hal pokok lainnya.

Talmud merupakan tradisi lisan yang sangat berwenang dalam agama Yahudi dihimpun dalam dua kumpulan yaitu Mishnah dan Gemara. Mishnah itu terkumpul dan ditulis sekitar tahun 200 M. Ia terkumpul dalam enam kitab atau perintah yang memuat kebijakan guru yang mengajarkan bagaimana Taurat seharusnya dijalankan untuk perilaku manusia dalam kehidupan sehari-hari. Pada saat pengumpulan Mishnah itu, bahasa orang-orang Yahudi telah berubah dari Ibrani (Hebrew) ke bahasa saudaranya - Aramic, bahasa pergaulan Timur-Tengah saat ini. Gemara merupakan Koleksi yang ditulis dalam bahasa Aramic. Istilah "Gemara" atau "penyelesaian", berbentuk tafsir pelengkap Mishnah. Mishnah dan Gemara bersama-sama membentuk Talmud"buku pelajaran". Menurut sebagian pendapat bahwa Talmud merupakan wahyu dari Tuhan yang tidak ditulis bersamaan dengan Taurat. ${ }^{22}$ Midrash merupakan kumpulan penjelasanpenjelasan kuno terhadap semua bagi Bibel. Istilah Midrash dari akar yang sama dari bahasa Arab yaitu "darasa" artinya "belajar".

Terdapat dua Istilah yang berkaitan dengan teks ajaran Agama Yahudi yaitu Halakhah dan Aggadah. Halakhah ini berkaitan dengan materi legal yang terdapat dalam Bibel, Talmud dan Midrash. Istilah Halakhah berarti "jalan menuju". Istilah ini mirip dengan istilah "syari'ah" dalam agama Islam yang berarti "jalan menuju sumber." Istilah "aggadah" digunakan untuk menyusun materi yang non-legal, seperti legenda, aphorisme dan kisah moral, disikusi dan debat teologi, syair, cerita rakyat, nasihat medis dan informasi lainnya. ${ }^{23}$

Ritual Keagamaan

Ritual keagamaan (religious ritual) merupakan aktivitas simbolik yang mempresentasikan nilai-nilai keagamaan. Dengan ritual keagamaan ini, kelompok penganut agama dapat memahami makna dan memperkuat kesadaran dirinya secara kolektif. Para penga-

22 Reuven Firestone, Children of Abraham- An Introduction to Judaism for Muslims, 119.

23 Reuven Firestone, Children of Abraham- An Introduction to Judaism for Muslims, 122. nut Yahudi menyembah hanya kepada Tuhan Yahweh. Terdapat beberapa bentuk ritual keagamaan dalam Agama Yahudi, baik yang berbentuk personal maupun kolektif. Bentuk ritual individu diantaranya; berdoa (bahasa Hebrew; terpillah, bahasa Aramic; selota) dan tzedakah. Bentuk ritual kolektif diantaranya doa komunal, dan membaca gulungan Taurat. Doa-doa tersebut dilakukan baik di Sinagog maupun di rumah. Waktu yang digunakan untuk aktivitas berdoa dilakukan pada setiap hari dan perayaan tertentu. Banyak perayaan sebagai ritual keagamaan dalam Agama Yahudi yang dilakukan pada saat-saat tertentu, diantaranya; sabath, berith, bat Mitzvah, pernikahan, kematian, rosh Hashanah, yom kippur, sukkot, pesach, Shavuot, Hanukkah, purim dan tishah av. Terdapat penambahan ritual dalam Agama Yahudi yang berhubungan dengan peristiwa politik seperti Yom ha-Sho'ah yaitu hari holocaust dikenal untuk memperingati penindasan bangsa Israel oleh Nazi Jerman. Yom ha-Atzma'ut yakni hari kemerdekaan dikenal untuk memperingati pendirian Negara Israel. Perayaan keagamaan Yahudi menjadi kalender keagamaan yang terdiri dari 12 bulan, yaitu Nisan, Iyar, Siwan, Tamus, Ab, Ekul, Tisyri, Markhesywan, Kislev, Tebet, Syebat, dan Adar.

Perilaku individu yang berkaitan dengan nilai-nilai ketuhanan adalah Tzedakah yang berarti pemberian harta kepada yang berhak menerimanya sebagai kewajiban beragama. Hebrew Bibel menegaskan untuk memberi makan kepada yang lapar, memberi pakaian kepada yang telanjang, menjaga anak yatim, janda dan orang miskin sebagai sifat ketuhanan (Kitab Ulangan 10:17-18).

Pengalaman Keagamaan

Pengalaman keagamaan (religious experience) merupakan keterlibatan individu secara sunyektif terhadap yang dianggap suci. Meskipun pengalaman itu secara esensi bersifat pribadi, tetapi masyarakat mencoba mengkomunikasikannya melalui ekspresi keyakinan dan dalam prilaku ritual. Pengalaman keagamaan dalam agama Yahudi bisa diekspresikan dalam gagasan pemikiran dan dalam ritual doa. Ekspresi pemikiran 
seperti dilakukan para Rabi dalam mengatur sistem keagamaan, para filosof dalam memahami kesakralan Agama Yahudi, dan orang-orang biasa sebagai pengikut agama Yahudi.

Para penganut Yahudi memiliki pengalaman dalam memahami Tuhan, Umat Pilihan, dan benda-benda tertentu. Sebagian pengikut Yahudi dalam tradisi kabalah mengakui bahwa Tuhan tidak mampu dikenal dan masih dalam pencapaian. Artinya Tuhan tersembunyi bagi penganut Yahudi di kedalaman wujud Tuhan, tetapi Tuhan mewahyukan kepada mereka malalui perilaku penciptaan dan terus menerus memelihara ciptaan itu. Para menganut Yahudi mengakui bahwa Tuhan mereka adalah Yahweh, tetapi nama itu jarang disebut karena untuk menjaga kesucian dilarang diucapkan disembarang tempat dan waktu. Umumnya mereka menyebut tuhan mereka dengan istilah "adonai" yang berarti "Tuhan kita".

Para filosof atau pemikir Yahudi terkadang berbeda dengan pemahaman umumnya dalam memahami penganut agama lain; seperti Saadialah Gaon (882-942) ${ }^{24}$ seorang pemikir Yahudi terpengaruh oleh pemikiran Islam berpendapat bahwa Tuhan adalah satu namun memiliki banyak sifat. Penegasan ini memberikan pemahaman bahwa bermacammacam agama sebagai sifat-sifat atau perwujudan yang berbeda dari satu Tuhan.

Dalam memahami umat pilihan, sebagian penganut Yahudi merasa bahwa agama dan bangsa tidak bisa dipisahkan. Mereka yakin bahwa Tuhan telah memilih mereka sebagai bangsa atau umat pilihan di dunia ini. Terbukti dengan adanya kontrak perjanjian Ibrahim dengan Tuhan dan adanya Taurat yang diberikan kepada Musa. Mereka juga merasa bahwa tanah Canaan adalah tanah yang dijanjikan Tuhan bagi orang-orang Israel sesuai dengan Taurat. Dalam menyikapi tembok ratapan para penganut Yahudi merasa bahwa tembok itu penuh bermakna terutama ketika berdoa mereka percaya bahwa Tuhan

${ }^{24}$ Harold Coward, Pluralisme, Challenge to World Religions, Terjemahan Bosco Carvalo. Cet. Ketiga. (Yogyakarta: Kanisius. 1994),15. akan mengabulkan segala permintaan. Paus Johanes Paulus II pernah berdoa di depan tembok Ratapan itu memohon kepada Tuhan diberi perdamaian di Timur Tengah. Perilaku itu diabadikan oleh pemerintah Israel dengan membuat perangko.

\section{Komunitas Keagamaan}

Komunitas Keagamaan (religious community) sebagai wujud keterlibatan masyarakat dalam suatu klompok atau golongan penganut keagamaan. Komunitas penganut keagamaan diatur secara formal dan informal. Komunitas Yahudi terorganisir dalam kelompok keagamaan yaitu penganut Agama Yahudi. Istilah Yahudi tidak hanya ditujukan untuk nama agama tetapi juga ditujukan kepada nama bangsa. Dalam sejarahnya istilah bagi orang-orang Yahudi mengalami perubahan istilah-istilah; seperti Hebrew, Israel, Judean Zionis dan Jews.

Istilah pemimpin komunitas Penganut Yahudi dalam sejarahnya mengalami perubahan mulai dari Partiarckh (zaman Ibrahim), kepala suku, Hakim, Raja sampai Rabbi. Namun dalam Negara Israel dipimpin oleh perdana Menteri. Sejak Tahun 70 S.M., terdapat komunitas Yahudi di Timur Tengah dan Afrika Utara termasuk Mesir dan Yunani dan Itali, Prancis, Spanyol, Jerman bahkan Inggris. Komunitas lama di Babilonia telah tumbuh juga, dan penghuni Bangsa Yahudi telah menembus Arab sampai Yaman.

Sebagai komunitas Agama, penganut Agama Yahudi berbeda dengan Kristen dan Islam. Perbedaan tersebut dikarenakan konsep keyakinan, prilaku dan pengalaman keagamaan. Kebanyakan orang-orang Yahudi menolak keberadaan Yesus sebagai juru selamat. Mereka beranggapan bahwa Juru Selamat yang benar akan membawa keselamatan, tidak memerlukan "kedatangan kedua". Para penganut Agama Yahudi meyakini bahwa konsep Trinitas merupakan hal yang bertentangan dengan keesaan Tuhan, terutama keyakinan Kristen bahwa Yesus adalah Anak Tuhan.

Begitu pula sikap penganut Agama Yahudi tidak mengakui ajaran Islam dikarenakan 
beberapa hal. Sebagaiamana Firestone $^{25}$ ungkapkan bahwa barangkali sebagaimana tradisi pada masa itu menegaskan bahwa Muhammad tidak sesuai dengan harapan mereka tentang seorang yang dinantikan. Hal ini jelas dalam Al-Qur'an bahwa walaupun wahyu-wahyu itu disebutkan berulang-ulang oleh Muhammad kepada masyarakat Madinah yang mirip dengan wahyu dalam Taurat tetapi berbeda dalam rinciannya. Orang-orang Yahudi curiga keotentikannya Al-Qur'an diwahyukan dalam bahasa Arab dan dalam kontek budaya Arab. Sebagaimana Taurat diwahyukan dalam bahasa Ibrani dan dalam konteks budaya bangsa Israel. Perbedaan gaya wacana ini mungkin menjelaskan banyak perbedaan. Tetapi ketidaksesuaian itu rupanya kurang bagi orang-orang Yahudi yang telah waspada terhadap apa yang mereka anggap penyimpangan makna Bibel Yahudi yang ditemukan dalam Perjanjian Baru dan interpretasi orang-orang Kristen.

Sejak dulu bangsa Yahudi adalah komunitas kecil yang selalu dikelilingi oleh masyarakat lainnya. Dalam Bibel bangsa Yahudi atau Israel disebut am segullah (umat tersayang) yang selalu memelihara hubungan baik dengan Tuhan. Komunitas Yahudi yang popular dibicarakan dan menjadi permasalah dunia hingga saat ini adalah Zionisme dan Israel.

Gerakan Zionis pada awalnya sebagai gerakan nasional sekuler yang tidak didasarkan pada aturan-aturan keagamaan, tetapi dipengaruhi oleh ide-ide Barat modern dari Negara sekuler yang merdeka dan modern. Walaupun mereka sangat kuat kesadarannya terhadap identitas Yahudi, tetapi mereka tidak merasa terpaksa untuk mengikuti hukum keagamaan. Tujuan utama mereka adalah imigrasi masa untuk menetapkan tanah air bangsa Yahudi agar mengatasi masalah besar dari anti semitisme di Eropa.

Orang-orang Yahudi yang taat secara keagamaan pada mulanya tidak mendukung bahkan mengutuk garakan zionisme. Kebanyakan diantara mereka adalah orang-orang Yahu-

\footnotetext{
${ }^{25}$ Reuven Firestone, Children of Abraham- An Introduction to Judaism for Muslims, 44.
}

di orthodox, alasan mereka bahwa mereka percaya bahwa tujuan menetapkan tanah air Yahudi mewakili sebuah upaya untuk "memperkuat Tangan Tuhan" dengan cara membawa keselamatan politik menurut kedudukan normatif orthodox, sedangkan beberapa upaya memperkuat Tangan Tuhan sebagaimana yang dilakukan pada masa lalu akan menghasilkan bencana. Seharusnya orang-orang Yahudi perlu menunggu dengan sabar sampai Tuhan memberi keputusan waktu untuk keselamatan yang abadi. Menurut mereka kekuatan sombong terhadap Tangan Tuhan oleh Zionist sekuler hanya akan menghasilkan kemarahan Tuhan dan menimbulkan bencana lain. Sampai hari ini sebagian penganut Yahudi Orthodoks mengutuk zionisme dan Negara Israel karena alasan ini, tetapi kebanyakan orang Yahudi yang taat sekarang mendukung Zionisme dan Negara Israel dengan sangat antusiasme.

Pendirian Negara Israel pada tahun 1948 seiring dengan semangat imperialism dan nasionalisme. Sebagian penganut Yahudi menganggap bahwa Israel adalah kombinasi dari Agama, Bangsa, dan ras karena organisasi dan definisi agama Yahudi berada pada aturan peradaban keagamaan nasional yang diwujudkan dalam bentuk keyakinan, ritual dan aturan-aturan perilaku anggota warga yang dibentuk bersama dan dihormati. Tetapi Negara Israel tidak mewakili seluruh penganut Agama Yahudi dunia, karena penganut Agama Yahudi tidak hanya terdapat di Israel melainkan di tempat-tempat lain, seperti di Amerika, Afrika Asia -termasuk di Indonesia.

\section{SIMPULAN}

Dari uraian di atas penulis dapat mengatakan beberapa hal, diantaranya; Yahudi merupakan kombinasi dari Agama, Budaya, Bangsa dan Ras. Yahudi sebagai fakta sejarah menunjukkan suatu kisah sejarah yang memiliki karakter spiritual, intelektual dan mampu mempertahankan identitasnya (survive). Secara sosiologis Yahudi termasuk agama karena memiliki unsur-unsur agama yaitu kepercayaan keagamaan, pengalaman keagamaan, ritual keagamaan dan komunitas 
keagamaan. Yahudi sebagai fakta sosial keagamaan telah berperan dan beriteraksi dengan masyarakat non-Yahudi baik dalam komunikasi konflik maupun integrasi. Hal ini penting untuk bahan pelajaran dalam memelihara perdamaian di masyarakat termasuk di

\section{DAFTAR PUSTAKA}

Ali Himayah, Mahmud. 2001. Ibnu Hazm wa minhajuh fi dirasah al-adyan, Terjemahan Halid Alkaf. Cet. Pertama. Jakarta: PT. Lentera Basritama.

Allegro, John M. 1972. The Chosen People- A Study of Jewish Hostory From The Time of The Exile Until The Revolt of Bar Kochba Sixth Century B.C. To Second Century A.D. New York: Double \& Company, INC.

Capps, Walter H. 1995. Religious Studies The Making of a Discipline. USA: Fortress Press.

Coward, Harold. 1988. Sacred Word and Sacred Text: Scripture in World Religions. New York: Orbis Books. . 1994. Pluralisme, Challenge to World Religions. Terjemahan Bosco Carvalo. Cet. Ketiga. Yogyakarta: Kanisius.

Dimont, Max I. 1993. Jews, God and History. Terjemahan Al Toro. Cet. Ke-1. Bandung: Eraseni Media.
Indonesia yang memiliki keanekaragaman agama dan budaya. Apabila ancaman konflik antar penganut agama bisa diatasi, maka memelihara integrasi di kalangan antar etnik perlu terus dijaga.

Fasching, Darrell J. and Dell deChant. 2001. Comparative Religious Ethics: a narrative approach. USA: Blackwell Publishers Ltd.

Firestone, Reuven. 2001. Children of Abraham- An Introduction to Judaisme for Muslims, USA: The Harriet and Robert Heilbrunn Institute for International Interreligious Understanding of the American Jewish Committee.

Green, Arthur. 1996. Jewish Spirituality From The Bible Through The Middle Ages. New York: The Crossroad Publishing Company.

McGuire, Meredith B. 1981. Religion, The social Context. California: Wadsworth,Inc.

Momen, Moojan. 1999. The Phenomenon of Religion- A Thematic Approach. Washington: Oneworld.

Relief- Journal of Religious Issues, Agama \& Sains I, No. 1 (2003).

Rives, Richard. 1966. Too Long in The Sun, Partakers Pub.

Smith, Huston. 1991. The Religions of Man. Terjemahan Saafroedin Bahar. Edisi Kedua. Jakarta: Yayasan Obor Indonesia. 